\title{
The Practice Degree of Democratic Behaviors of Male and Female Principals at the Public Basic Schools in Their Tasks Performance in Bani Obeid District, from the Standpoints of Their Teachers
}

\author{
Mufadi Al- Momani ${ }^{1} \&$ Mahmoud Hasan Ajlouni ${ }^{2}$ \\ ${ }^{1}$ AL-Balqa Applied University, Jordan \\ ${ }^{2}$ AL-Balqa Applied University, Jordan \\ Correspondence: Mufadi Al- Momani, AL-Balqa Applied University. Jordan. \\ Received: May 2, 2018 Accepted: May 16, 2018 Online Published: May 29, 2018 \\ doi:10.5539/res.v10n3p12 URL: https://doi.org/10.5539/res.v10n3p12
}

\begin{abstract}
The study aimed to identify the practice degree of democratic behaviors of male and female principals at the public basic schools in their tasks performance at Bani Obeid district, from the standpoints of their teachers. A questionnaire prepared by Abu-Hayja' in (2005) was developed to achieve this goal, and it consist of (46) items in its final version. The study populations consist of all male and female teachers at the public basic schools in Bani Obeid district, and (560) of those were selected as the study sample, in order to reach the objectives. For data analysis, the arithmetic means and standard deviations of the responses were calculated about the practice degree of democratic behaviors by their teachers, where ANOVA and MANOVA were used, and then they were statistically processed using SPSS. The study results showed the existence of statistically significant differences at the significance level of $(\alpha=0.05)$ between the subjects estimates of the practice degree of democratic behaviors of basic schools principals in their tasks performance that could be attributed to the teacher's sex and years of experience variables. The results also showed a non-existence of statistically significant differences at level $(\alpha=0.05)$ between the arithmetic means related to the practice degree, as a whole that could be attributed to the variables of qualification, experience, and sex.
\end{abstract}

Keywords: democratic behaviors, male and female principals, public basic schools, Bani Obeid district, practice degree, tasks performance

\section{Introduction}

The school considers one of the most important humanitarian organizations on the earth surface, due to the very huge numbers of student who attend these schools, between the ages of 4 and 18, and the school as an educational institution carries out the task of preparing generations and make them ready for the future. The school is no longer a place for education only, but it become concerned about all of the intellectual, spiritual, and physical aspects of the learner or student, and this great importance of school, at no doubt reflect on the importance of school management (Al-Bohi \& Bayoumy, 2012).

Democracy in the modern age has achieved a historical victory, over all other alternatives and regimes, where everyone today and from the various intellectual trends: patriots and nationalists, religious and secular, and centrist and leftist declare their favoritism of democracy, and they talk about the advantages of democratic governance, where democracy became, as a governance system, identical to the concept of legitimacy in the modern political life, with all decisions, laws, and policies are acceptable and justifiable, if it were taken in a democratic way (Bani Salameh, 2011).

The emergence of democratic education, impose on the systems new roles and responsibilities that make it necessary to care about it, where democratic education led to expansion in the educational services, and submit them to different group of students, more than ever, and therefore the task of education is no longer identification and selection of individuals who weren't provided with the educational opportunities, but its mission become to provide the conditions, that help everyone reach the desired fate, which their readiness permit, and this require teachers to prepare themselves and get ready to face that through getting familiar with the diverse cultural and social backgrounds, in order to define the students educational needs and help them adapt to the learning environments (Ibrahim, 2010).

There are no doubt, that education democracy became an issue that its roots hit in the depth of educational philosophies and educational policies in the developed countries, and its branches launch to deal with all the issues, perspectives, and elements that related to the education in general, and basic education in particular, in addition education democracy looks like an educational and learning issue externally, but cultural, political, and social issue in its essence, where democracy 
forms in the educational system are in the vast majority of it, natural extension of democracy in the society (Abu Sharaa, 2008).

Unfortunately, lots of our schools are seen as traditional in its ways, methods, means, and ideas, where the employees in it must work according to specific, strict, and firm rules, that don't allow for creative and innovative spirit to appear, develop, and evolve with its members, and this will expose the educational process for deficiency and wrong doing, due to the management practices perform by some of the principals, which characterized by a lack of democratic spirit in it, therefore it became important to care and pay attention to the school administration and develop it, and train staffs in it on the modern management methods, in order to make from the principal an educational leader who own the ability to achieve the educational goals.

\section{Study Problem \& Questions}

Many teachers and students complain about the non-democratic behaviors of their schools' principals, and the control and sway of those principals to make the school related decisions alone, at the same time as a lot of principals claim their behaviors characterize as a democracy. The study problem represents the practice degree of male and female principals' democratic behaviors in their tasks performance, from the standpoints of their teachers. The study will address the following questions, related to the problem:

1. What is the practice degree of democratic behaviors of public basic schools male and female principals at their tasks performance, from the standpoints of their teachers?

2. Is there any statistically significant differences at the level $(\alpha=0.05)$, between the study sample members' estimates, for the democratic behaviors practice degree of public basic schools male and female principals in their tasks performance, due to the teacher variables of sex, qualifications, and years of experience?

\section{Study goals}

The study aimed to identify the practice and implementation degree of basic governmental schools male and female principals, in Bani Obeid District, to the democracy principles and behaviors, from the standpoints of their teachers.

\section{Study importance}

The study of management styles in the educational administration represent a critical importance, where the leadership style of male and female principals impact employees' performance, productivity, and job satisfaction, and while management practices the democratic leadership style, it would lead to facilitate the work and encourage employees to do it, which leads school to achieve its desired objectives.

\section{Previous studies}

Al-Masaeid conducted a study (2012) that aimed to identify the democratic principles, and its level of implementation by the principals of public basic schools in the Northern Badiya District, from the teachers' perspective, and showed the differences in their perspectives, depending on experience and qualifications. The study found that most democratic principles were practiced by the schools principals, according to the perspective of teachers at the public basic school in the Northern Badiya District were related to the field of justice and equality, but the least practiced democratic area was the aspect of participating in the decision making process. The study also found a non-existence of statistically significant differences, due to the qualification, while there are statistically significance differences, due to years of experience and in favor of long expertise.

But the study of Al-Reemy (2011), entitled: "The practice level of College of Education faculty members to the democratic values", aimed to detect the practice level of faculty members at the College of Education, to the democratic values at Sana'a University, and reached the following results: the practice took positive indication for the values of equality and human relations, while it took negative indication for the values of participation and freedom, according to the perspective of students, and it also refer to a positive practice of the democratic values, from the point of view of faculty members, for all values and at high degree. In addition, the study arrived to results that suggest the existence of differences in the practice level, due to the sex variable on the human relations and participation, and in favor of male.

While the study of (Bahmueller, 2009) aimed to develop an international general framework for education in the democratic world, and at first the author wonders about the possibility of reaching an international agreement related to the meaning of democracy and education, in order to provide the democratic citizen, and the author says that for the purpose of answering this question, a collaborative project has been created and managed by the civic educational center in the city of Calabasas, California. The objectives of this project summarizes in developing the general framework of democracy, and the development means creating a renewed definition clearance for the meaning of democracy, where it enable educators; in any country to prepare their students to become an active citizens, and at responsible level in the democratic country. 
But the study of (Alfano, 2008) entitled: "Teacher perceptions before the service, toward the meaning and the purpose of democratic education in the rural schools". The purpose of this study that conducted in America was to develop a new strategy for directing the individual attention and concern in the teacher training programs, to introduce the international educational innovations and restorations, and encourage teachers to get a scientific qualification or a degree during the service, to recognize the objectives of democratic education. The study results showed that training teachers, in the framework of principles and concepts related to the democratic education in an academic atmosphere, will contribute significantly to the employment of modern educational methods, such as exploration and dialogue, and the enhancement of teachers' democratic principles, which lead to an effective education.

\section{Study Methodology}

\subsection{Procedural Definitions}

Male and Female principals: they are the individuals who manage the basic schools in the educational directorate of Bani Obeid district.

\subsection{Study Limitations}

The study was limited to the female and male teachers of public basic schools, in the directorate of education of Bani Obeid district, for the academic year (2012/2013), with the exception of teachers who were hired on the supplemental education account.

\subsection{Methods \& Procedures}

This description deal with an explanation for the study population, study sample and its selection method, its description of the study tool used, its implementation procedures, study variables, and the statistical analysis used to arrive to the results related to the study questions.

\subsection{Study Population}

The study population consist of all male and female teachers at the public basic schools in Bani Obeid District, who amounted to (560) male and female teachers for the school year (2012/2013), and the following table shows the distribution of study population members, according to the town and sex variables:

Table 1. Distribution of population members, according to the town and sex variables

\begin{tabular}{lll}
\hline Town & Male & Female \\
\hline Assarih & 75 & 80 \\
Huson & 77 & 81 \\
Alnymh & 50 & 47 \\
Aidoun & 45 & 40 \\
Kittem & 28 & 25 \\
Shatana & 6 & 6 \\
\hline
\end{tabular}

\subsection{Study Sample}

The study sample consisted of all members of population, due to its small size, from the point view of researcher, and the easy access to all its members.

\subsection{Study Tool}

A questionnaire prepared by Abu Al-Hayja (2005) was used in this study, which was developed to measure the implementation level of democratic principles at the basic school principals in Irbid governorate, from the viewpoint of teachers. To ensure the validity of questionnaire to be implemented on the population of this study, the researcher developed it and revised it to include (46) paragraphs; in its final form and gave each paragraph of the tool listed weight, according to Likert fifth scale. 
Table 2. Distribution of the questionnaire paragraphs on the five areas of study

\begin{tabular}{lll}
\hline Field/Areas & Paragraphs & Paragraphs total \\
\hline Team spirit work principle & $1-10$ & 10 \\
Participate in decision making & $11-19$ & 9 \\
Justice \& equality & $20-28$ & 9 \\
Authorities and powers delegation & $29-37$ & 9 \\
Freedom of opinion and expression & $38-46$ & 9 \\
\hline
\end{tabular}

\subsection{Tool Consistency and Sincerity}

The researcher was satisfied with the consistency and sincerity procedures that were performed by Abu Al-Hayja, to verify the consistency and sincerity of the tool.

\subsection{Study Procedures}

- Permission was obtained from the officials of the Ministry of education to implement the tool.

- Researcher interviewed male and female principals and met with the concerned teachers, and also clarifies the study importance.

The researcher depends on the consistency and sincerity of the tool extracted by Abu Al-Hayja, and distributed the questionnaire by hand on the sample members of (560) male and female teachers, scattered on the educational locations and schools of Assarih, Huson, Alnymh, Aidoun, Kittem, and Shatana, and where retrieved in the same way, after explaining to the sample members how to fill the questionnaire, and after answering their questions, with emphasis on the importance of accuracy and objectivity, where this information will be used for research purposes only. The total number of recovered questionnaire were (336) with (60\%) of the study population, which were analyzed and the results generated from it, by using the computer and SPSS program.

\subsection{Statistical Treatment}

1. The one-sided analysis of variance for the study tool (ANOVA).

2. Multivariate analysis of variance for the study tool (MANOVA).

\section{Study Results Display, Discussion, and Recommendations}

This section provide an overview of the study results, discuss it, and interpret it, and also display the recommendations and suggestions of the researcher, where the purpose of this study was to identify the practice degree of democratic behaviors of male and female principals at the public basic schools in their tasks performance at Bani Obeid District, from the standpoints of their teachers:

First: the results related to answering the question which stated: "What is the practice degree of democratic behaviors of male and female principals at the public basic schools in their tasks performance at Bani Obeid District, from the standpoint of their teachers?"

In view of the many results related to this question, and in order to simplify the presentation and display of its results, the researcher saw to divide it into two parts, as follow:

\section{a) In relation to the study tool and its areas:}

The arithmetic means, standard deviations, and observed frequencies were calculated for the study tool and its areas, as in table (3): 
Table 3. Arithmetic means, standard deviations, and observed frequencies for the study tool and its areas

\begin{tabular}{|c|c|c|c|c|c|c|c|c|c|c|}
\hline $\begin{array}{l}\text { Area } \\
\text { number }\end{array}$ & Area content & $\begin{array}{l}\text { Area } \\
\text { rank }\end{array}$ & $\begin{array}{l}\text { Very } \\
\text { small }\end{array}$ & Small & Medium & Large & $\begin{array}{l}\text { Very } \\
\text { large }\end{array}$ & $\begin{array}{l}\text { Arithmetic } \\
\text { mean }\end{array}$ & STDEV & $\begin{array}{l}\text { Practice } \\
\text { degree }\end{array}$ \\
\hline 1 & Team spirit work principle & 1 & 11 & 20 & 48 & 87 & 64 & 3.750 & 0.76 & 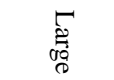 \\
\hline 3 & Justice \& equality principle & 2 & 14 & 24 & 55 & 80 & 57 & 3.612 & 0.86 & \\
\hline 4 & $\begin{array}{l}\text { Authorities \& powers } \\
\text { delegation principle }\end{array}$ & 3 & 17 & 31 & 58 & 74 & 50 & 3.469 & 0.84 & 胥 \\
\hline 5 & $\begin{array}{l}\text { Freedom of opinion \& } \\
\text { expression principle }\end{array}$ & 4 & 20 & 34 & 65 & 71 & 41 & 3.343 & 0.94 & \\
\hline 2 & $\begin{array}{l}\text { Participate in decision } \\
\text { making principle }\end{array}$ & 5 & 25 & 35 & 64 & 69 & 34 & 3.206 & 0.90 & \\
\hline \multicolumn{3}{|c|}{$\begin{array}{l}\text { The practice degree of democratic behaviors of male and } \\
\text { female principals at the public basic schools in their tasks } \\
\text { performance at Bani Obeid District, from the standpoint } \\
\text { of their teachers. }\end{array}$} & 17 & 29 & 58 & 76 & 49 & 3.482 & 0.76 & 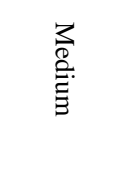 \\
\hline
\end{tabular}

It notices from table (3) that the results came within the following ranks:

1. The area of team spirit work principle came in the first place with an arithmetic mean of (3.750), within a large practice degree.

2.The area of justice \& equality principle came in the second place with an arithmetic mean of (3.612), and also within a large practice degree.

3.The area of authorities \& power delegation principle came in the third place with an arithmetic mean of (3.469), within a medium practice degree.

4.The area of freedom of opinion \& expression principle came in the fourth place with an arithmetic mean of (3.343), within a medium practice degree.

5. Finally, the area of participation in the decision making principle came in the fifth and last place with an arithmetic mean of (3.206), and also within a medium practice degree.

Knowing that, the degree of overall practice, came within an arithmetic mean degree of (3.482).

\section{b) In relation to the paragraphs of study tool areas:}

To simplify the display of results related to this part, it has been divided into five items, as follows:

1.In regard to the paragraphs of team spirit work principle: the arithmetic means, standard deviations, and observed frequencies were calculated for the paragraphs of team spirit work principle area, as in table (4) 
Table 4. Arithmetic means, standard deviations, and observed frequencies for the paragraphs of team spirit

\begin{tabular}{|c|c|c|c|c|c|c|c|c|c|c|}
\hline $\begin{array}{l}\text { Paragraph } \\
\text { number }\end{array}$ & $\begin{array}{lll}\text { Team spirit } & \text { work } \\
\text { principle } & & \\
\end{array}$ & $\begin{array}{l}\text { Paragraph } \\
\text { rank }\end{array}$ & $\begin{array}{l}\text { Very } \\
\text { small } \\
\end{array}$ & Small & Medium & Large & $\begin{array}{l}\text { Very } \\
\text { large } \\
\end{array}$ & $\begin{array}{l}\text { Arithmetic } \\
\text { mean }\end{array}$ & STDEV & $\begin{array}{l}\text { Practice } \\
\text { degree }\end{array}$ \\
\hline 7 & $\begin{array}{l}\text { Teachers take a look at } \\
\text { most incoming official } \\
\text { speeches and books to the } \\
\text { school }\end{array}$ & 1 & 4 & 16 & 30 & 83 & 97 & 4.1 & 0.99 & $\underset{\substack{0 \\
0}}{\stackrel{0}{0}}$ \\
\hline 1 & $\begin{array}{l}\text { Encourage teachers to } \\
\text { develop the spirit of } \\
\text { cooperation and teamwork }\end{array}$ & 2 & 7 & 9 & 37 & 98 & 79 & 4.013 & 0.97 & \\
\hline 2 & $\begin{array}{l}\text { Encourage teachers to } \\
\text { develop social relations }\end{array}$ & 3 & 8 & 11 & 42 & 78 & 91 & 4.013 & 1.04 & \\
\hline 4 & $\begin{array}{l}\text { Consider and respect the } \\
\text { social, humanitarian, and } \\
\text { professional circumstances } \\
\text { of teachers. }\end{array}$ & 4 & 9 & 21 & 53 & 66 & 81 & 3.822 & 1.13 & \\
\hline 5 & $\begin{array}{l}\text { Encourage and stimulate } \\
\text { the spirit of } \\
\text { entrepreneurship, } \\
\text { innovation, and creativity } \\
\text { upon teachers and students }\end{array}$ & 5 & 8 & 15 & 50 & 98 & 59 & 3.804 & 1.01 & \\
\hline 3 & $\begin{array}{l}\text { Fosters the spirit of } \\
\text { communication between } \\
\text { teachers and students }\end{array}$ & 6 & 11 & 19 & 44 & 98 & 58 & 3.752 & 1.07 & \\
\hline 6 & $\begin{array}{l}\text { Encourage group activities } \\
\text { among the students }\end{array}$ & 7 & 9 & 24 & 47 & 101 & 49 & 3.683 & 1.04 & \\
\hline 8 & $\begin{array}{l}\text { Ensure the local community } \\
\text { participation in school } \\
\text { activities }\end{array}$ & 8 & 10 & 28 & 56 & 94 & 42 & 3.565 & 1.06 & \\
\hline 10 & $\begin{array}{l}\text { Play an active role in } \\
\text { helping teachers to } \\
\text { overcome the difficulties } \\
\text { that face them }\end{array}$ & 9 & 20 & 31 & 56 & 82 & 41 & 3.404 & 1.23 & $\frac{3}{3}$ \\
\hline 9 & $\begin{array}{l}\text { Discuss the exams' results } \\
\text { with the teachers, in order } \\
\text { to develop corrective plans } \\
\text { for students with low } \\
\text { academic achievement }\end{array}$ & 10 & 25 & 28 & 63 & 71 & 43 & 3.34 & 1.23 & \\
\hline
\end{tabular}

It notices from table (4) that paragraphs with the ranks (1-8), recorded an arithmetic means ranging from (3.656-4.100) respectively in descending order, with large practice degrees for each rank, and standard deviations ranging between (97-1.13), while the paragraphs $(9 \& 10)$ recorded an arithmetic means amounted to (3.404\& 3.343$)$ respectively, in descending order, within a medium practice degree and standard deviations of (1.18 \& 1.23)) respectively.

2. In regard to the paragraphs (participate in decision making principle): The arithmetic means, standard deviations, and observed frequencies were calculated for the paragraphs (participate in decision making principle) area, as in table (5): 
Table 5. Arithmetic means, STDEV, and observed frequencies for paragraphs of participation in the decision making

\begin{tabular}{|c|c|c|c|c|c|c|c|c|c|c|}
\hline $\begin{array}{l}\text { Paragraph } \\
\text { number }\end{array}$ & $\begin{array}{l}\text { Participation in the decision } \\
\text { making principle area }\end{array}$ & $\begin{array}{l}\text { Paragraph } \\
\text { rank }\end{array}$ & $\begin{array}{l}\text { Very } \\
\text { small }\end{array}$ & Small & Medium & Large & $\begin{array}{l}\text { Very } \\
\text { large }\end{array}$ & $\begin{array}{l}\text { Arithmetic } \\
\text { mean }\end{array}$ & STDEV & $\begin{array}{l}\text { Practice } \\
\text { degree }\end{array}$ \\
\hline 19 & $\begin{array}{l}\text { Teachers participate in holding } \\
\text { regular meetings to assess work } \\
\text { progress, and give advice and } \\
\text { guidance }\end{array}$ & 1 & 10 & 32 & 46 & 101 & 41 & 3.570 & 1.07 & 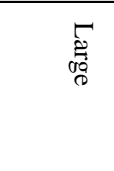 \\
\hline 18 & $\begin{array}{l}\text { Teachers participate in the plan of } \\
\text { different activities at school level }\end{array}$ & 2 & 15 & 22 & 58 & 93 & 42 & 3.543 & 1.10 & \\
\hline 17 & $\begin{array}{l}\text { Teachers participate in making } \\
\text { internal decisions when there's an } \\
\text { emergency that concern school }\end{array}$ & 3 & 17 & 44 & 57 & 67 & 45 & 3.296 & 1.20 & : \\
\hline 11 & $\begin{array}{l}\text { Teachers participate in developing } \\
\text { and implementing school plans }\end{array}$ & 4 & 26 & 30 & 64 & 70 & 40 & 3.213 & 1.23 & \\
\hline 12 & $\begin{array}{l}\text { Teachers participate in work } \\
\text { evaluation and implementation of } \\
\text { educational decisions. }\end{array}$ & 6 & 22 & 4 & 74 & 65 & 29 & 3.113 & 1.15 & \\
\hline 15 & $\begin{array}{l}\text { Parents participate in solving } \\
\text { school problems in general }\end{array}$ & 7 & 40 & 47 & 73 & 59 & 29 & 3.004 & 1.16 & \\
\hline 13 & $\begin{array}{l}\text { Student Council participate in the } \\
\text { planning and managing of school } \\
\text { activities }\end{array}$ & 8 & 40 & 39 & 60 & 62 & 16 & 2.600 & 1.28 & \\
\hline 16 & $\begin{array}{l}\text { Parents and teachers participate in } \\
\text { evaluating curriculum and } \\
\text { textbooks and filed it for } \\
\text { stakeholders }\end{array}$ & 9 & 53 & 58 & 63 & 40 & 16 & 3.004 & 1.21 & \\
\hline
\end{tabular}

It notices from table (5) that paragraphs (18\&19), recorded an arithmetic means of (3.570\& 3.543) respectively in descending order, with large decision making principle for each of them, and standard deviations of (1.10\& 1.07) respectively, while the paragraphs with the ranks (11-17) recorded an arithmetic means ranged between (2.60-3.34), with a medium decision making principle and standard deviations of (1.15-1.28).

3. In regard to the paragraphs (justice \& equality principle): the arithmetic means, standard deviations, and observed frequencies were calculated for the paragraphs of (justice \& equality principle) area, as in table (6): 
Table 6. Arithmetic means, standard deviations, and observed frequencies for the paragraphs of (justice \& equality)

\begin{tabular}{|c|c|c|c|c|c|c|c|c|c|c|}
\hline $\begin{array}{l}\text { Paragraph } \\
\text { number }\end{array}$ & $\begin{array}{lcc}\text { (Justice } \quad \& \quad \text { equality } \\
\text { principle) area }\end{array}$ & $\begin{array}{l}\text { Paragraph } \\
\text { rank }\end{array}$ & $\begin{array}{l}\text { Very } \\
\text { small }\end{array}$ & Small & Medium & Large & $\begin{array}{l}\text { Very } \\
\text { large }\end{array}$ & $\begin{array}{l}\text { Arithmetic } \\
\text { mean }\end{array}$ & STDEV & $\begin{array}{l}\text { Practice } \\
\text { degree }\end{array}$ \\
\hline 24 & $\begin{array}{l}\text { Implement the instructions } \\
\text { of success and completion } \\
\text { rates on all students } \\
\text { according to the laws and } \\
\text { regulations at the Ministry } \\
\text { of education }\end{array}$ & 1 & 10 & 19 & 51 & 83 & 67 & 3.774 & 1.09 & 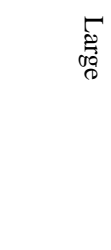 \\
\hline 21 & $\begin{array}{l}\text { Equals between teachers } \\
\text { when distributing the } \\
\text { quotas in lesson table }\end{array}$ & 2 & 18 & 17 & 53 & 77 & 65 & 3.670 & 1.19 & \\
\hline 25 & $\begin{array}{l}\text { Apply the laws, } \\
\text { regulations, and } \\
\text { instructions on teachers } \\
\text { and students objectively } \\
\text { and neutrally }\end{array}$ & 3 & 9 & 26 & 55 & 90 & 50 & 3.635 & 1.06 & \\
\hline 22 & $\begin{array}{l}\text { Deal with students on the } \\
\text { fairness basis and } \\
\text { democracy, consider their } \\
\text { views, and take the right } \\
\text { ones }\end{array}$ & 4 & 14 & 19 & 66 & 76 & 55 & 3.604 & 1.12 & \\
\hline 23 & $\begin{array}{l}\text { Provides the advice and } \\
\text { guidance for teachers and } \\
\text { focuses on the positive } \\
\text { trends in their area of work }\end{array}$ & 5 & 9 & 29 & 57 & 84 & 51 & 3.604 & 1.08 & \\
\hline 26 & $\begin{array}{l}\text { Give all teachers and } \\
\text { students a sense of respect } \\
\text { and equal treatment }\end{array}$ & 6 & 18 & 23 & 53 & 78 & 58 & 3.587 & 1.19 & \\
\hline 20 & $\begin{array}{l}\text { Evaluate teachers with the } \\
\text { highest objectivity }\end{array}$ & 7 & 15 & 23 & 57 & 83 & 52 & 3.583 & 1.14 & \\
\hline 28 & $\begin{array}{l}\text { Work to fight the clannish } \\
\text { between students and } \\
\text { teachers }\end{array}$ & 8 & 20 & 30 & 46 & 68 & 66 & 3.565 & 1.27 & \\
\hline 27 & $\begin{array}{l}\text { Respond to students with } \\
\text { special needs }\end{array}$ & 9 & 15 & 30 & 61 & 77 & 47 & 3.483 & 1.15 & 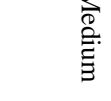 \\
\hline
\end{tabular}

It notices from table (6) that paragraphs with the ranks (20\&26), in addition to paragraph (28) recorded an arithmetic means between (3.565-3.774) respectively in descending order, with large (justice \& equality principle) for each of them, and standard deviations range between (1.06-1.27) respectively, while the paragraph with the rank (27) recorded an arithmetic means of (3.483), with a medium (justice \& equality principle) and standard deviation of (1.15).

4. In regard to the paragraphs (Authorities \& powers delegation principle)area : the arithmetic means, standard deviations, and observed frequencies were calculated for the paragraphs of (Authorities \& powers delegation principle)area, as in table (7): 
Table 7. Arithmetic means, STDEV, and observed frequencies for paragraphs of (Authorities \& powers delegation) area

\begin{tabular}{|c|c|c|c|c|c|c|c|c|c|c|}
\hline $\begin{array}{l}\text { Paragraph } \\
\text { number }\end{array}$ & $\begin{array}{l}\text { (Authorities \& powers } \\
\text { delegation principle)area }\end{array}$ & $\begin{array}{l}\text { Paragraph } \\
\text { rank }\end{array}$ & $\begin{array}{l}\text { Very } \\
\text { small }\end{array}$ & Small & Medium & Large & $\begin{array}{l}\text { Very } \\
\text { large }\end{array}$ & $\begin{array}{l}\text { Arithmetic } \\
\text { mean }\end{array}$ & STDEV & $\begin{array}{l}\text { Practice } \\
\text { degree }\end{array}$ \\
\hline 36 & $\begin{array}{l}\text { Assign to } \\
\text { second-in-command or } \\
\text { assistant the powers to } \\
\text { manage school and run its } \\
\text { affairs in their absence }\end{array}$ & 1 & 4 & 14 & 27 & 73 & 112 & 4.196 & 0.99 & 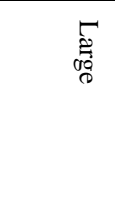 \\
\hline 34 & $\begin{array}{l}\text { Authorize teachers the } \\
\text { competence to supervise } \\
\text { building maintenance and } \\
\text { cleanliness, and school } \\
\text { facilities }\end{array}$ & 2 & 15 & 29 & 49 & 86 & 51 & 3.561 & 1.16 & \\
\hline 32 & $\begin{array}{l}\text { Engages student council in } \\
\text { following up students daily } \\
\text { absence, and informing } \\
\text { school management about it }\end{array}$ & 3 & 20 & 28 & 61 & 70 & 51 & 3.452 & 1.21 & 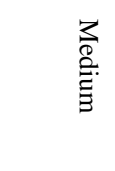 \\
\hline 29 & $\begin{array}{l}\text { Delegate part of their powers } \\
\text { to some teachers who are } \\
\text { able to solve the sudden } \\
\text { daily problems in school, to } \\
\text { develop their leadership } \\
\text { spirits }\end{array}$ & 4 & 21 & 24 & 64 & 75 & 46 & 3.439 & 1.19 & \\
\hline 37 & $\begin{array}{l}\text { Develop joint plans for the } \\
\text { joint teacher per subject, to } \\
\text { improve their performance } \\
\text { and raise students level of } \\
\text { achievement }\end{array}$ & 5 & 17 & 30 & 68 & 71 & 44 & 3.413 & 1.16 & \\
\hline 35 & $\begin{array}{l}\text { Authorize teachers and } \\
\text { students the power to } \\
\text { oversee, develop, and } \\
\text { beautify the school garden }\end{array}$ & 6 & 20 & 35 & 57 & 71 & 47 & 3.391 & 1.22 & \\
\hline 30 & $\begin{array}{l}\text { Delegate to students the } \\
\text { management of some school } \\
\text { activities to develop their } \\
\text { leadership spirit }\end{array}$ & 7 & 17 & 41 & 53 & 76 & 43 & 3.378 & 1.19 & \\
\hline 31 & $\begin{array}{l}\text { Engages student council in } \\
\text { managing some school } \\
\text { activities }\end{array}$ & 8 & 20 & 40 & 64 & 71 & 35 & 3.265 & 1.17 & \\
\hline 33 & $\begin{array}{l}\text { Involve teachers and parents } \\
\text { in school activities planning } \\
\text { and sponsoring it }\end{array}$ & 9 & 22 & 40 & 77 & 70 & 21 & 3.122 & 1.1 & \\
\hline
\end{tabular}

It notices from table (7) that paragraphs (34\&36), recorded an arithmetic means of (3.561\& 4.196) respectively in a descending order, with large (authorities \& powers delegation principle)area for each of them, and standard deviations of (1.16\&0.99) respectively, while the paragraphs with the ranks $(29,30,31,32,33,35,36)$ recorded an arithmetic means ranged between (3.122-3.452), with a medium (authorities \& powers delegation principle)area and standard deviation ranged between (1.10-1.22).

5. In regard to the paragraphs (freedom of opinion \& expression principle) area: the arithmetic means, standard deviations, and observed frequencies were calculated for the paragraphs of (freedom of opinion \& expression principle)area, as in table (8): 
Table 8. Arithmetic means, STDEV, and observed frequencies for paragraphs of (freedom of opinion \& expression) area

\begin{tabular}{|c|c|c|c|c|c|c|c|c|c|c|}
\hline $\begin{array}{l}\text { Paragraph } \\
\text { number }\end{array}$ & $\begin{array}{l}\text { (Freedom of opinion \& } \\
\text { expression principle)area }\end{array}$ & $\begin{array}{l}\text { Paragraph } \\
\text { rank }\end{array}$ & $\begin{array}{l}\text { Very } \\
\text { small }\end{array}$ & Small & Medium & Large & $\begin{array}{l}\text { Very } \\
\text { large }\end{array}$ & $\begin{array}{l}\text { Arithmetic } \\
\text { mean }\end{array}$ & STDEV & $\begin{array}{l}\text { Practice } \\
\text { degree }\end{array}$ \\
\hline 43 & $\begin{array}{l}\text { Accepts teacher's opinions } \\
\text { and suggestions during the } \\
\text { official meetings }\end{array}$ & 1 & 17 & 20 & 54 & 68 & 71 & 3.678 & 1.21 & $\stackrel{2}{\stackrel{0}{0}}$ \\
\hline 38 & $\begin{array}{l}\text { Gives students the } \\
\text { opportunity to express } \\
\text { their opinions freely and } \\
\text { openly, within educational } \\
\text { disciplines }\end{array}$ & 2 & 15 & 22 & 52 & 86 & 55 & 3.626 & 1.14 & \\
\hline 40 & $\begin{array}{l}\text { Listen to parents opinions } \\
\text { about the school level and } \\
\text { its effectiveness }\end{array}$ & 3 & 10 & 18 & 67 & 90 & 45 & 3.617 & 1.02 & \\
\hline 42 & $\begin{array}{l}\text { Recognize teachers } \\
\text { opinions and the } \\
\text { mechanisms to implement } \\
\text { it in the area of raising } \\
\text { students scientific level }\end{array}$ & 4 & 10 & 29 & 61 & 92 & 38 & 3.517 & 1.05 & \\
\hline 41 & $\begin{array}{l}\text { Show concern about the } \\
\text { suggestions provided from } \\
\text { teachers to develop the } \\
\text { training programs during } \\
\text { service }\end{array}$ & 5 & 17 & 28 & 72 & 80 & 33 & 3.365 & 1.1 & 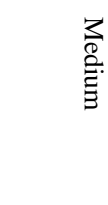 \\
\hline 39 & $\begin{array}{l}\text { Encourage open meetings } \\
\text { between students and } \\
\text { teachers to listen to their } \\
\text { opinions about their } \\
\text { problems. }\end{array}$ & 6 & 31 & 35 & 67 & 63 & 34 & 3.148 & 1.24 & \\
\hline 46 & $\begin{array}{l}\text { Encourage the educational } \\
\text { development council to } \\
\text { provide suggestions about } \\
\text { improving the education } \\
\text { process }\end{array}$ & 7 & 31 & 46 & 61 & 58 & 34 & 3.078 & 1.26 & \\
\hline 44 & $\begin{array}{l}\text { Encourage the open } \\
\text { regular meetings between } \\
\text { students and teachers to } \\
\text { see their opinions about } \\
\text { teaching methods }\end{array}$ & 8 & 21 & 53 & 73 & 89 & 24 & 3.052 & 1.13 & \\
\hline 45 & $\begin{array}{l}\text { Encourage students to } \\
\text { write the reports that carry } \\
\text { their opinions and } \\
\text { treatment of their daily } \\
\text { problems }\end{array}$ & 9 & 26 & 56 & 74 & 39 & 35 & 3.004 & 1.22 & \\
\hline
\end{tabular}

It notices from table (8) that paragraphs $(38,40,42,43)$, recorded an arithmetic means ranged between (3.517- 3.678) respectively in descending order, with large (freedom of opinion \& expression principle)area for each of them, and standard deviations that ranged between (1.02-1.21) respectively, while the paragraphs with the ranks $(39,41,44,45,46)$ recorded an arithmetic means ranged between (3.004-3.365), with a medium (freedom of opinion \& expression principle)area and standard deviation ranged between (1.10-1.26).

Second: the results related to answering the question which stated: "Is there any statistically significant differences at the level $(\alpha=0.05)$, between the study sample members' estimates, for the democratic behaviors practice degree of public basic schools male and female principals in their tasks performance at Bani Obeid District, from the standpoints of their teachers due to the study variables of sex, qualifications, and years of experience?" 
In view of the many results related to this question, and in order to simplify the presentation and display of its results, the researcher saw to divide it into two parts, as follow:

\section{a. In relation to the general indicator (Study tool):}

The Arithmetic means and standard deviations were calculated for the study tool according to the different categories and levels of each study variables, as in table (9):

Table 9. Arithmetic means and STDEV for the overall practice degree of behaviors, according to the study variables

\begin{tabular}{llll}
\hline Independent variable & Categories & Arithmetic means & STDEV \\
\hline \multirow{2}{*}{ Qualifications } & Less than Bachelor & 3.664 & 0.781 \\
& Bachelor and higher & 3.461 & 0.76 \\
\multirow{2}{*}{ Years of experience } & Less than 2 yrs & 3.628 & 0.5 \\
& 2 yrs and more & 3.443 & 0.82 \\
\multirow{2}{*}{ Sex } & Male & 3.567 & 0.83 \\
& Female & 3.39 & 0.68 \\
\hline
\end{tabular}

It notices from table (9) the existence of virtual differences between the arithmetic means related to the overall practice degree, according to the different categories and levels of each study variables, and in order to verify the substantial variances or virtual differences, the single variance analysis of factorial design $(2 ; 2 ; 2)$ was performed for the main effects, as in table (10):

Table 10. Results of single variance analysis for the overall practice degree of democratic behaviors

\begin{tabular}{lllllll}
\hline Variance source & SS & DF & MS & F-value & Statistical Sig & Scientific Sig \\
\hline Qualification & 0.547 & 1 & 0.547 & 0.955 & 0.329 & $0.4 \%$ \\
experience & 1.645 & 1 & 1.645 & 2.872 & 0.092 & $1.3 \%$ \\
Sex & 2.113 & 1 & 2.113 & 3.690 & 0.056 & $1.6 \%$ \\
Error & 129.437 & 226 & 0.573 & & & \\
Overall & 133.593 & 229 & & & & \\
\hline
\end{tabular}

It shows from table (10) the non-existence of statistically significant differences at level $(\alpha=0.05)$ between the arithmetic means related to overall practice degree, due to any of the study variables (qualification, experience, and sex).

\section{b. In relation to the special indicator (Study tool areas):}

The Arithmetic means and standard deviations were calculated for the study tool areas, according to the different categories and levels of each study variables, as in table (11):

Table 11. Arithmetic means and STDEV for the secondary practice degree of democratic behaviors, for each one of the study tool principle, separately according to the study variables

\begin{tabular}{|c|c|c|c|c|c|c|c|c|}
\hline $\begin{array}{l}\text { Independent } \\
\text { variable }\end{array}$ & Category & Statistical & $\begin{array}{l}\text { Team spirit } \\
\text { work } \\
\text { principle }\end{array}$ & $\begin{array}{l}\text { Participate in } \\
\text { decision making } \\
\text { principle }\end{array}$ & $\begin{array}{l}\text { Justice } \\
\text { equality } \\
\text { principle }\end{array}$ & $\&$ & $\begin{array}{l}\text { Authorities and } \\
\text { powers delegation } \\
\text { principle }\end{array}$ & $\begin{array}{l}\text { Freedom of opinion } \\
\text { and expression } \\
\text { principle }\end{array}$ \\
\hline \multirow{4}{*}{ Qualification } & Less than & Mean & 3.958 & 3.417 & 3.787 & & 3.583 & 3.542 \\
\hline & Bachelor & STDEV & 0.78 & 0.91 & 0.83 & & 0.88 & 0.89 \\
\hline & Bachelor & Mean & 3.726 & 3.181 & 3.591 & & 3.455 & 3.32 \\
\hline & and higher & STDEV & 0.75 & 0.90 & 0.87 & & 0.84 & 0.94 \\
\hline \multirow{4}{*}{$\begin{array}{l}\text { Yrs. } \\
\text { experience }\end{array}$} & \multirow{2}{*}{$\begin{array}{l}\text { Less than } 2 \\
\text { yrs. }\end{array}$} & Mean & 3.773 & 3.324 & 3.808 & & 3.653 & 3.565 \\
\hline & & STDEV & 0.59 & 0.64 & 0.52 & & 0.73 & 0.71 \\
\hline & \multirow{2}{*}{$\begin{array}{l}2 \text { yrs. and } \\
\text { higher }\end{array}$} & Mean & 3.744 & 3.175 & 3.560 & & 3.420 & 3.284 \\
\hline & & STDEV & 0.80 & 0.96 & 0.93 & & 0.87 & 0.98 \\
\hline \multirow{3}{*}{ Sex } & \multirow{2}{*}{ Male } & Mean & 3.850 & 3.335 & 3.772 & & 3.413 & 3.434 \\
\hline & & STDEV & 0.80 & 0.97 & 0.90 & & 0.91 & 1.00 \\
\hline & Female & Mean & 3.643 & 3.067 & 3.439 & & 3.529 & 3.245 \\
\hline
\end{tabular}


It notices from table (11) the existence of virtual differences between the arithmetic means related to the secondary practice degree, for each area of the study tool according to the different categories and levels of each study variables, and in order to verify the substantial variances or virtual differences, it's a must to use either the single variance analysis or the multiple variance analysis, and in order to determine which one of them should be used, the correlation relationships were calculated between the areas, as in table (12):

Table 12. Virtual correlation relationship of the study tool principles

\begin{tabular}{|c|c|c|c|c|}
\hline & $\begin{array}{l}\text { Team spirit work } \\
\text { principle }\end{array}$ & $\begin{array}{l}\text { Participate in decision making } \\
\text { principle }\end{array}$ & $\begin{array}{l}\text { Justice \& equality } \\
\text { principle }\end{array}$ & $\begin{array}{l}\text { Authorities and powers } \\
\text { delegation }\end{array}$ \\
\hline $\begin{array}{l}\text { Participate in decision making } \\
\text { principle }\end{array}$ & $0.77 *$ & & & \\
\hline Justice \& equality principle & $0.74 *$ & $0.79 *$ & & \\
\hline $\begin{array}{l}\text { Authorities and powers } \\
\text { delegation principle }\end{array}$ & $0.60^{*}$ & $0.73^{*}$ & $0.70^{*}$ & \\
\hline $\begin{array}{l}\text { Freedom of opinion and } \\
\text { expression principle }\end{array}$ & $0.73^{*}$ & $0.77^{*}$ & $0.79^{*}$ & $0.76^{*}$ \\
\hline
\end{tabular}

* Significant at error probability of $\geq 0.05$

It notices from table (12) that correlation relationships between the study tool areas were statistically significant at level $(\alpha=0.05)$, in addition to its significant value and according to that multiple variance analysis of factorial design $(2 ; 2 ; 2)$ was performed for the main effects, as in table (13):

Table 13. Results of multiple variance analysis for the secondary practice degree of democratic behaviors

\begin{tabular}{llllllll}
\hline The effect & Multiple test & $\begin{array}{l}\text { Multiple } \\
\text { test value }\end{array}$ & $\begin{array}{l}\text { Calc. overall } \\
\text { F-value }\end{array}$ & $\begin{array}{l}\text { Theory } \\
\text { DF }\end{array}$ & $\begin{array}{l}\text { Error } \\
\text { DF }\end{array}$ & $\begin{array}{l}\text { Statistical } \\
\text { Sig }\end{array}$ & $\begin{array}{l}\text { Scientific } \\
\text { Sig }\end{array}$ \\
\hline Qualification & $\begin{array}{l}\text { Hotelling's } \\
\text { Trace }\end{array}$ & 0.008 & 0.339 & 5 & 222 & 0.889 & $0.8 \%$ \\
Experience & $\begin{array}{l}\text { Hotelling's } \\
\text { Trace }\end{array}$ & 0.043 & 1.902 & 5 & 222 & 0.095 & $4.1 \%$ \\
Sex & $\begin{array}{l}\text { Hotelling's } \\
\text { Trace }\end{array}$ & 0.161 & $7.169^{*}$ & 5 & 222 & 0.000 & $13.9 \%$ \\
\hline
\end{tabular}

* Significant at error probability of $\geq 0.05$

It notices from table (13) the existence of statistically significant effect at level $(\alpha=0.05)$, in the democratic behaviors secondary practice degree of the study tool principles due to the independent study variable (Sex), while the existence of statistically significant effect for the rest of independent study variables weren't approve, and in order to verify any of the study tool areas had the effect of sex variable, the single variance analysis of factorial design $(2 ; 2 ; 2)$ was performed for the main effects, as in table (14):

Table 14. Results of single variance analysis for secondary practice degree of democratic behaviors, for each separately

\begin{tabular}{|c|c|c|c|c|c|c|c|}
\hline Variance source & Dependent variable & SS & DF & MS & F-value & Statistical Sig & Scientific Sig \\
\hline \multirow{2}{*}{ Qualification } & Team spirit work & 0.875 & 1 & 0.875 & 1.545 & 0.215 & $0.7 \%$ \\
\hline & Participate in decision making & 0.718 & 1 & 0.718 & 0.902 & 0.343 & $0.4 \%$ \\
\hline
\end{tabular}




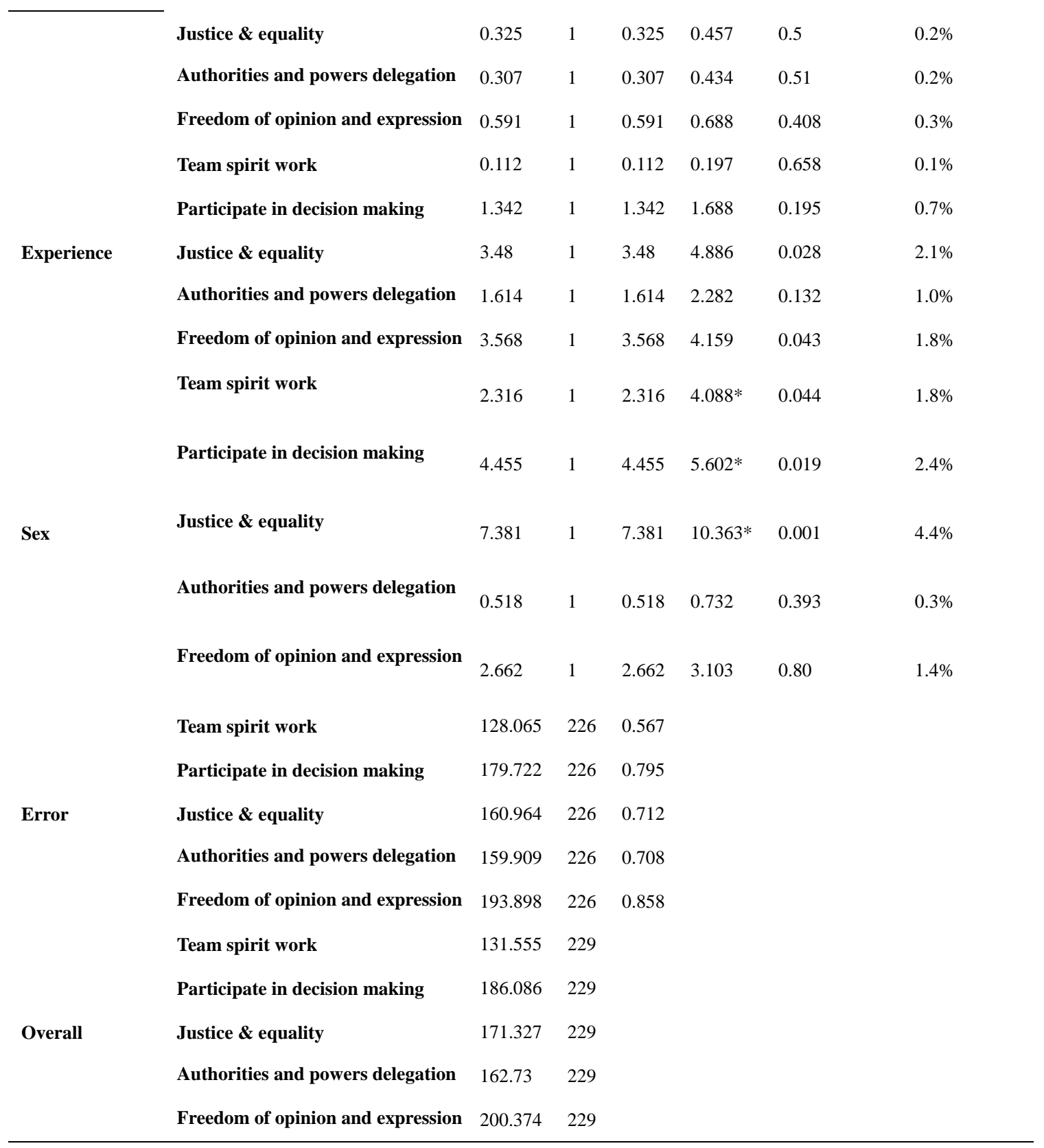

* Significant at error probability of $\geq 0.05$

It notices from table (14) the existence of statistically significant effect at level $(\alpha=0.05)$, for the secondary practice degree due to the independent study variable (Sex) on the secondary areas, Team spirit work principle, Participate in decision making principle, and Justice \& equality principle, while it didn't show an effect for appointing the study variables.

\section{Third: Discuss the results related to first question}

The results related to first question, which states: "What is the practice degree of democratic behaviors of public basic schools male and female principals at their tasks performance, from the standpoints of their teachers?" showed that "team spirit work principle" ranked first with an arithmetic mean of (3.75), followed by the "principle of Justice and equality", and then came the "principle of authorities and powers delegation", followed by the "freedom of opinion and expression principle", and finally the "principle of participation in decision making" ranked last.

Researcher sees that rank of "team spirit work principle" first, considers good thing in the area of educational management, which is an evidence on the maturity of school managing departments, while the rank of "principle of participation in decision making" in the last place, with medium practice degree considers risky or dangerous matter in the educational management field, and its according to the researcher opinion a reflection of the dictatorship principle in decision making, 
which the school principal was raise on as a student, teacher, and then as a principle and stayed with him, and didn't benefit much from the modern management principles and trends that principal studied during the preparation and qualification period for the school management. These results are consistent with the study results of (Al-Swalmah, 2000 \& Al-Masaeid, 2001).

The researcher also found in regard to the paragraphs of "team spirit work principle" area, that paragraph "Teachers take a look at most incoming official speeches and books to the school" ranked first in terms of arithmetic mean, and the large practice degree, which is expected by the researcher, due to the managerial responsibility presented upon the school principal, to inform the teachers about the official books, but in relation to the last paragraph in this area, "Ensure the local community participation in school activities", it came last, but with large practice degree, and the researcher attribute the reason for that to the principal need of local community to the moral and material cooperation with it, in order to support and promote the school, where the paragraph "Play an active role in helping teachers to overcome the difficulties that face them" got a medium practice degree, but it had higher arithmetic mean than the paragraph "Discuss the exams' results with the teachers, in order to develop a corrective plan for students with low academic achievement", and the researcher explains the reason for that to the unfriendly relationship between the principal and teachers, or due to the principal's interest in the topics that present him (her) as a principal, in term of non-methodological activities, and strengthen his (her) role in front of officials and authorities.

In relation to the (participate in decision making principle) area that took the last place, in terms of arithmetic mean and medium practice degree, the two paragraphs: "Teachers participate in holding regular meetings to assess work progress, and give advice and guidance" and "Teachers participate in the plan of different activities at the school level" and clarify this issue by the need to conduct periodic meetings to study the letters and textbooks send by the general directorates of schools. In addition to the need for principal and teachers to meet regularly to examine the issues and matters related to the school, where teachers consider the key element for implementing the educational and school activities, which makes it necessary for the school principal to involve teachers in planning for it.

\section{Fourth: Discuss the results related to second question}

In relation to the second question, which states: "Is there any statistical significant differences at the level ( $\alpha=0.05)$, between the study sample members' estimates, for the democratic behaviors practice degree of public basic schools male and female principals in their tasks performance, due to the teacher variables of sex, qualifications, and years of experience?" the results of general indicator (study tool) showed the non-existence of significant differences at $(\alpha=0.05)$ between the arithmetic means related to the overall practice degree, due to any of the variables (qualification, experience, sex), and the researcher explains this matter by the concept of democracy which grows with humans since theyoung age, and during the age of twenty this concept would have matured in a good way. In addition, the teaching and working in the education field would help to understand and assimilate this concept much better.

In terms of experience, the researcher sees that results came opposite to what had been assumed and also opposite to the personal belief of the researcher, where the researcher assumes that experience helps to develop the concept of democracy, and therefore increase the sensitivity of paragraphs to detect the practice degree of school principals to the democratic principles.

In terms of sex, the researcher didn't expect an effect of sex, where democracy is a concept that human races live through, regardless of sex. These results are consistent with the study of (Al-Hashyan, 2000 \& Al-Swalmah, 2000), in terms of the non-existence of differences due to sex, the study of (Al-Hashyan, 2000), in terms of the non-existence of statistically significant differences due to experience, and the study of (Masaeid, 2001) in terms of the non-existence of statistically significant differences due to qualification.

In relation to the correlation relationships between the study tool areas, it was statistically significant at $(\alpha=0.05)$, and these correlations range between (0.60-0.79), and somewhat reflect the good relationships between each one of them, which confirms that paragraphs somewhat based on measuring the same characteristic.

The study results indicated a statistically significant effect for the secondary practice degree, which attribute to sex in the following areas: The team spirit work principle, the participation in decision making principle, and the principle of Justice and equality, and in favor of males. The researcher attributes this matter to the degree of freedom and power that males enjoy, and to the patriarchal education in society that gave they power at statistically significant differences more than females.

In general, the researcher sees some bright aspects in the field of democracy, but there are some sections and areas that study results revealed a moderate or weak practices in it, which makes the researcher to recommend more attention and concern by the Ministry of education to the area of decision making participation, and the area of authority delegation to male and female principals. 


\section{References}

Abu Alhija, Rahman (2005). Democratic principles and its implementation at basic public school principals of Irbid governorate, from the perspective of teachers. Unpublished master thesis. Yarmouk University. Irbid-Jordan.

Alfano, Micmhael (2011). Pre-service teacher" perceptions and the meaning and purpose of democratic education in urban schools: A case study. CRE IC, DAI - A 62/09.p.3016.mar 2002.

Abu Sharah, Khalid \& Gapari, Thair (2008). Future education indications and ambition. Amman. Edition 1. Arab Society library for publication and distribution

Bahmueller, C. (2009). Developing on international framework for Education in democracy. Office of Educational Research and improvement (ED). Washington DC. (E00036). U.S. Indiana

Bani Salameh, Mohamed (2011). Democratic transformation process in the Sultanate of Oman. Al-Manara. Vol. 13. No. 7.

Bohi, Farouk \& Bayoumy, Mohamed (2012). School elementary management. Cairo. Dar Al-kitab

Ibrahim, M. (2010). Democracy and education, toward a future vision in the democracy and education in the Arab world. Arabic Unity Studies Center. P.O. box 521

Masaeid, Mufadi (2012). The Democratic principles and its implementation level at the managers of public secondary schools in Northern Badiya Brigade from the viewpoint of teachers. Unpublished master thesis. Yarmouk University. Irbid-Jordan

Powers, Stephen (2000). Human right is orientation of prospective of social stoolies teachers in Nigeria Social Studies. V48. No.6. pp276

\section{Copyrights}

Copyright for this article is retained by the author(s), with first publication rights granted to the journal.

This is an open-access article distributed under the terms and conditions of the Creative Commons Attribution license (http://creativecommons.org/licenses/by/4.0/). 